\title{
Honoré de Balzac, La Fanciulla dagli occhi d'oro
}

\section{Marco Stupazzoni}

\section{Q OpenEdition}

\section{Journals}

\section{Edizione digitale}

URL: http://journals.openedition.org/studifrancesi/2198

DOI: $10.4000 /$ studifrancesi.2198

ISSN: 2421-5856

\section{Editore}

Rosenberg \& Sellier

\section{Edizione cartacea}

Data di pubblicazione: 1 aprile 2014

Paginazione: 161

ISSN: 0039-2944

\section{Notizia bibliografica digitale}

Marco Stupazzoni, « Honoré de Balzac, La Fanciulla dagli occhi d'oro », Studi Francesi [Online], 172 (LVIII I

I) | 2014, online dal 01 avril 2014, consultato il 18 septembre 2020. URL : http://

journals.openedition.org/studifrancesi/2198; DOI : https://doi.org/10.4000/studifrancesi.2198

\section{Questo documento è stato generato automaticamente il 18 settembre 2020.}

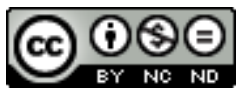

Studi Francesi è distribuita con Licenza Creative Commons Attribuzione - Non commerciale - Non opere derivate 4.0 Internazionale. 


\title{
Honoré de Balzac, La Fanciulla dagli
} occhi d'oro

\author{
Marco Stupazzoni
}




\section{NOTIZIA}

HONORÉ DE BALZAC, La Fanciulla dagli occhi d'oro, cura e traduzione di Lucio CHIAVARELLI. edizione integrale, Roma, Grandi Tascabili Economici Newton, 2012, pp. 126.

Pubblicato in prima edizione tra l'aprile 1834 e il maggio 1835, La Fille aux yeux d'or costituisce l'ultimo tassello narrativo della trilogia che porta il titolo di: Histoire des Treize. La presente edizione italiana dell'opera balzachiana, curata nella traduzione e nell'apparato delle note al testo da Lucio Chiavarelli, è compresa nella collana dei «Grandi Tascabili Economici» (n. 698) della Newton Compton Editori di Roma. Il testo di Balzac è preceduto da un puntuale saggio introduttivo dello stesso Chiavarelli (Introduzione, pp. 7-14) e da una Nota biobibliografica sulla vita, sull'opera e sulla ricezione critica di Balzac.

Dedicato ad Eugène Delacroix, La Fille aux yeux d'or è, tra tutti i romanzi brevi di Balzac, quello che, meglio e più di ogni altro, scrive Chiavarelli, esemplifica la «mostruosa triplice natura: di narratore, di politico e di pittore» (p. 7) dello scrittore francese. Il curatore evidenzia l'importanza di quest'opera e la sua fondamentale novità nella produzione narrativa balzachiana e ne sottolinea «l'inattesa e misteriosa unità» (p. 12). La Fille aux yeux d'or, osserva l'A., è un'opera scritta «da due narratori che tentano in continuazione di sopraffarsi reciprocamente: il Balzac-affarista cinico, obiettivo, analitico sino all'esasperazione e il Balzac-indagatore del cuore umano, appassionato, sintetico sino al mistero» (p. 11). Attraverso il racconto di una torbida e lacerante passione amorosa nel caotico contesto parigino che la contiene, Balzac spezza l'unicità prospettica della narrazione e allarga «il territorio dove esercitare le sue analisi a tutta la realtà sociale» (p. 14). 